\title{
Operational Slack and Venture Survival
}

\author{
Arash Azadegan \\ Supply Chain Management and Marketing Science Department, Rutgers Business School, 1 Washington Park Newark, New Jersey 07102, \\ USA, aazadegan@business.rutgers.com \\ Pankaj C. Patel \\ Miller College of Business, Ball State University, Muncie, Indiana 47306, USA, pcpatel@bsu.edu \\ Vinit Parida \\ Division of Entreprenuership, Luleå University of Technology, 97187, Luleå, Sweden, vinit.parida@ltu.se
}

\begin{abstract}
lack can act as a double-edged sword. While it can buffer against environmental threats to help ensure business continuity, slack can also be costly and reduce profitability. In this study we focus on operational slack, the form related to the firm's production processes. We investigate the role of operational slack on firm survival during its venture stage when its survival is significantly challenged by environmental threats. Specifically, we explore how change in three types of environmental uncertainty, namely dynamism, complexity, and lack of munificence, affect the relationship between operational slack and venture survival. Results suggest that with an increase in environmental uncertainty, operational slack lowers the likelihood of venture failure.
\end{abstract}

Key words: operational slack; uncertainty; venture survival; gamma frailty Weibull regression History: Received: August 2010; Accepted: December 2011 by Vinod Singhal, after 3 revisions.

\section{Introduction}

The concept of organizational slack, which has been defined as resources in excess of what is needed to conduct firm activities (Bourgeois 1981, Nohria and Gulati 1996), has created much debate in management literature. There has been extensive evidence describing how organizational slack enhances an organization's ability to weather unexpected disturbances and thus ensure business continuity (Bradley et al. 2010, Wan and Yiu 2009). By carrying slack resources, firms have been buffered against varying forms of disruptions (Chopra and Sodhi 2004, Hendricks and Singhal 2005). Conversely, advocates for resource efficiency have shown how excessive slack resources can limit competitiveness (Adler et al. 2009). For instance, a rich stream of research on lean management practices has highlighted how trimming excess resources and reducing waste enhances profitability and financial performance (Womack et al. 1990).

A prevalent means for firms to carry slack is in their operations. Operational slack consists of temporal, labor, or physical excesses in the firm's production process. For instance, maintaining surplus production capacity, slack labor, or spare physical inventory are common forms by which firms carry excess resources to mitigate potential environmental fluctuations (Caputo 1996, Hendricks et al. 2009). In any of these forms, operational slack allows added "degrees of freedom" to quickly remedy a number of possible disruptions.

Reducing the risk of disruptions is particularly important from two perspectives - firm age and environmental uncertainty. From the perspective of firm age, disruptions challenge the survival of a firm during its early life-cycle stages. Compared with larger and older firms, liabilities of newness and smallness make a new venture more susceptible to the damage from external disturbances (Carroll 1983, Stinchcombe 1965). Investing in operational slack can help buffer a venture's technical core; however, due to liabilities of newness and smallness investing in operational slack can carry heavy costs for a young venture (Brush et al. 2001). Although carrying operational slack can act as a buffer to ward off debilitating disturbances, it can also act as an added expense that further increases the chance of venture failure. Second, when a firm is exposed to increased environmental uncertainty, its successful operation in dynamic, complex, or hostile environments not only requires protecting the venture against the perils of the environment, but also highlights the need for careful selection and use of resources. The effectiveness of operational slack under these challenging environmental contexts requires investigation; however, evidence that operational slack's effectiveness 
for venture survival and under different environmental contexts has been scarce in the literature.

We address this gap in the literature by suggesting that operational slack acts as both a "shock-absorbing buffer" that guards against disruptions, and as a "risk reduction strategy" that improves the venture's chance of survival (Shepherd et al. 2000). However, we also acknowledge the fact that operational slack can be expensive and can even lower the venture's financial performance (George 2005). Nevertheless, given survival as the primary objective of a venture, we propose that any financial loss may play a secondary role to warding off possibly damaging environmental threats. As will be shown, the versatility and quickness resulting from operational slack allows the venture to act more rapidly, more effectively, and with more self-reliance to various unforeseen events. Despite the venture's inherent liabilities of newness and smallness, by maintaining a consistent and rapid pace of production, ventures can maintain business continuity and increase their chance of survival (Esteve-Perez and Manez-Castillejo 2008, Jovanovic 1982).

This study intersects operations management and entrepreneurship, a less emphasized but timely and relevant area of cross-disciplinary research (Kickul et al. 2011, Phan and Chambers 2012) and offers multiple contributions to the literature. First, it provides theoretically based and empirically validated insights on the role of operational slack. To our knowledge a comprehensive assessment of the role of operational slack under varied environmental contexts, and contingent on firm age, has been lacking. Second, this study contributes to the entrepreneurship literature by focusing on a less emphasized element of a venture's capabilities, namely that related to its operation. Last, we use archival venture data to test operational outcomes and employ analytical methods not typically applied in operations management literature.

\section{Operational Slack}

Operational slack can take the form of surplus capacity (Bourland and Yano 1994, Steele and Papke-Shields 1993), extra time (AhmadBeygi et al. 2010, Caputo 1996), excess labor (Steele and Papke-Shields 1993, Vollman et al. 1992), or spare physical inventory (Hendricks and Singhal 2009, Voss et al. 2008). We define operational slack as temporal, labor, or physical excesses in the production processes.

Rich research streams have explored the role of operational slack. Mainstream production planning research has focused on identifying the level, location, and type of operational slack necessary to enhance production (e.g., Guide and Srivastava 1998, Metters and Vargas 1999). For instance, Caputo (1996) listed and explained the types of slack useful under different production settings. Others have used finite scheduling policies to determine the effects of slack inventory and capacity under different production conditions. For example, Hendricks (1992) used a Markovian chain model to determine the extent that buffer allocation can be used to control process variability. Another notable example is the works of Atwater and colleagues (e.g., Atwater and Chakravorty 2002, Atwater et al. 2004). These authors applied a finite loading policy known as Drum-BufferRope (Goldratt and Cox 1986) to limit the production system to one bottleneck while using inventory slack to protect against variations.

In organization management, operational slack has been categorized as absorbed slack, a form that is less discretionary and harder to redeploy (Bourgeois 1981, Greve 2003, Tan and Peng 2003). The general rationale for this categorization is that operational slack tends to be embedded in production operations which makes it harder to retrieve and use for other purposes (Love and Nohria 2005). Empirical evidence suggests otherwise (Huang and Chen 2010). For instance, Voss et al. (2008) showed that operational slack can be easy to obtain and generic in use. Sharfman et al. (1988) considered operational slack in the form of raw materials inventory and flexible machine capacity to be highly discretionary. Operations management research has focused on the practical applications of operational slack by identifying how its different forms can enhance performance (e.g., Bartezzaghi and Verganti 1995, Ketzenberg et al. 2003, Metters and Vargas 1999). For instance, Kleindorfer and Saad (2005) considered operational slack as an important means for mitigating supply chain disruptions. In contrast, others have highlighted how slack can limit productivity. Literature on lean manufacturing, for example, has highlighted the high costs associated with maintaining slack (Inman and Mehra 1993, Karlsson and Ahlstrom 1997).

We can gain several insights from this literature review. First, the literature shows split evidence on the positive or negative effects of operational slack and is silent on its relationship with venture survival. Second, although operational slack may be conceptually subsumed under broader concepts of buffering, redundancy, or flexibility, operational slack can also be a distinct construct. Buffering aims to reduce the firm's dependencies and raise its self-reliance through a variety of ways (Thompson 1967). As Bode et al. (2011) note, the buildup of slack is one of several ways to buffer the firm from its environment. For instance, inventory buffer is only one form of demand smoothing. Redundancy can explain duplication in a system (Chopra and Sodhi 2004). While operational slack could be a source of redundancy, there are other ways 
to introduce redundancy. For instance, redundancy can be introduced by having overlapping departmental jurisdictions, or by carrying multiple suppliers (Anupindi and Akella 1993). Lastly, flexibility explains how well a firm can respond and react to its environment (Anand and Ward 2004), a possible outcome of leveraging operational slack.

The third insight gained from the literature relates to the characteristics of operational slack that can make it useful as a buffer against environmental threats. First, operational slack can be redeployed quickly because it can be transformed rapidly and with low conversion cost. This can allow operational slack to be turned into productive use easily and efficiently (Mishina et al. 2004, Steele and Papke-Shields 1993). It comes as no surprise that firms have used onsite inventory of supply material to address production issues caused by sudden demand increases. Second, the generic nature of operational slack (Voss et al. 2008), has allowed for it to be versatile in addressing a range of situations (Hambrick and D'Aveni 1988). For example, physical inventory and machine surplus time can be applied to a broad set of production-related issues from raw material shortages to demand fluctuations.

These characteristics, namely ease in redeployment and versatility, have made operational slack useful to any size operation, but perhaps particularly useful to a venture. Given its inherent limitations, a venture needs to be highly selective when investing in resources (Brush et al. 2001). Operational slack could not only be useful in the venture's production process, but it could also be easily redeployed to face a range of unforeseen environmental threats. Part of the secret to success in survival under uncertainty is to capitalize on favorable circumstances (Wan and Yiu 2009). Operational slack can help the venture to be prepared in taking advantage of opportunities, thereby lowering its chance of failure (Haveman 1992). In short, operational slack fits the characteristics of what is labeled in venture research as risk reduction strategies, which help limit the "downside risks" facing the venture (Shepherd et al. 2000). However, just like other risk reduction strategies, operational slack can be expensive and can limit profitability.

Operational slack has rarely, if at all, been studied in entrepreneurship research. Instead, venture researchers have primarily focused on slack in financial forms. These measures included the difference between current assets and current liabilities (Bradley et al. 2011, Mishina et al. 2004), current ratio and debt to equity ratio (De Carolis et al. 2009), cash and cash receivables (Patzelt et al. 2008), and cash reserves (Bradley et al. 2010). To our knowledge no research has evaluated the effects of operational slack in terms of excess capacity, human slack, and excess inventory on venture survival. In the next section, we explore whether operational slack can help or hinder venture survival.

\section{Theory and Hypotheses}

\subsection{Operational Slack and Venture Survival}

The venture formation and growth process includes acquiring resources, defining the scope of the venture, and developing exchanges with other organizations (Smith et al. 2001). Venture survival requires this process to occur while warding off internal and external disturbances. During the startup stage ventures carry significant limitations. Literature has labeled these as liabilities of newness (Stinchcombe 1965), which stem from lack of established routines in managing the venture's internal activities. Many of the procedures and processes in a new venture are also not well established. Efficient and reliable operational routines may be lacking. Moreover, the venture's personnel can be unfamiliar with their roles, which widen the effect of the venture's inefficiencies. Newness also means that the venture's exchange relationships with its clients, creditors, suppliers, and other organizations are yet to be fully established or stabilized.

Once established, better operational routines, established procedures, familiarity of the managers with the business, and increased acquaintance with customers can help mitigate the effects of environmental uncertainty. In the meantime, the young venture needs to guard itself through risk-reduction strategies such as operational slack (Shepherd et al. 2000). A lack of organizational experience may mean that even simple mistakes can become costly disturbances (Liao et al. 2009). Given the easy-to-redeploy and versatile nature of operational slack, it can aid in quickly buffering the venture's production process against internally caused distresses. Survival also depends on the venture's ability to effectively adapt to changes imposed by its customers, suppliers, or the business outset (Baum and Bird 2010). By buffering the young venture from these external effects, operational slack ensures continuity in its production. However, this sustained operation is not without cost to the venture and can be at the expense of lowered profits. While operational slack provides a buffer to maintain a venture's business continuity against external threats, it may affect how the firm manages its production capacity, labor, and inventory. Nevertheless, unlike its larger and older competitors that can focus on increased profitability and efficiency, a venture's foremost objective is to survive. By foregoing the benefits of increased utilization of its assets, ventures could reduce their upside potential margins (Shepherd et al. 
2000) or would have to "miss the boat." However, by not carrying operational slack, ventures could "sink the boat." In summary, without operational slack, the venture may remain defenseless against environmental threats, thereby increasing its risk of failure.

Hypothesis 1 (H1): Operational slack reduces the likelihood of failure.

In the following sections we explore the influence that operating under different forms of environmental uncertainty may have.

\subsection{Environmental Dynamism and Operational \\ Slack}

Dynamic environments carry faster pace and greater magnitude of change (Heeley et al. 2006, Rosenzweig 2009). An example of a dynamic environment is a competitive industry where the presence of multiple players implies continual changes to pricing and to products (Ju and Zhao 2009). When operating in less dynamic environments, a venture has time to adapt. As the environment becomes more dynamic, it is more difficult to predict, prepare for, or effectively respond to change. In other words, ventures may find it increasingly difficult to assess the environment, forecast its effects, and develop responses (Milliken 1987). For instance, increased environmental dynamism can limit and change accurate production information, making demand forecasting difficult. Increased dynamism can also change the competitive landscape of the environment and therefore negatively affect availability of supply (Patel et al. 2012).

The key to survival in a dynamic environment is immediacy of venture reaction to change (Bradley et al. 2011), a justification for keeping slack in reserve. Having easily deployable operational slack can help ensure that a venture continues to produce products consistently despite the challenges of a dynamic environment. Operational slack - in the form of capacity, labor, or inventory-ensures the continuity of production despite the more rapid pace of change. However, continuity offered through operational slack is not free and may be at the expense of lowered use of a venture's assets. Nevertheless, without operational slack the young firm may have difficulty in quickly addressing the damaging effects of unforeseen environmental change in dynamic settings.

While dynamic environments can be challenging for a young firm, they can also provide opportunities that can raise its probability of survival. Changes to products and the appearance and disappearance of different players in a competitive environment imply new business prospects. Leveraging such opportunities is best accomplished by ventures that can quickly respond. Operational slack allows for the venture to be ready to exploit such opportunities. For instance, by carrying excess capacity or slack labor, the venture has a better chance of introducing novel products or accommodating changing customer demands (Azadegan and Dooley 2010). In other words, operational slack can allow for ventures to take more risks and to experiment with new opportunities in a dynamic environment (Nohria and Gulati 1996). Overall, increased environmental dynamism presents both operational opportunities and operational threats. Under these conditions, operational slack can be useful in both mitigating threats and facilitating experimentation and risk taking. Therefore:

Hypothesis 2 (H2): Environmental dynamism moderates the relationship between operational slack and venture failure, such that with increasing operational slack at higher levels of environmental dynamism the likelihood of venture failure is reduced.

\subsection{Environmental Complexity and Operational Slack}

It is important to note the differences between operating in dynamic environments and complex environments. Dynamism is defined as "instability and turbulence" (Dess and Beard 1984, p. 55), whereas complexity is "the heterogeneity and range" of activities in the environment (Child 1972, p. 3).

Complex environments have been described as those in which many different inputs are used or many different outputs are produced (Dess and Beard 1984, Heeley et al. 2006). In complex environments, the presence of a multitude of factors and the interplay among them are the cause of change. As a result, complex environments make identifying and responding to the cause of change difficult. For instance, in a complex supply chain it may be hard to pinpoint whether the root cause of a production shortage is a quality issue in the raw material, a delivery issue with a supplier, or a process issue during the product's final assembly.

Operating in complex environments can be particularly challenging for a venture because of its liabilities of smallness (Bruderl and Schussler 1990). Liabilities of newness (Stinchcombe 1965) have implied that the young firm does not have coherently established operational competencies. In addition, its lack of resources limits the young firm's ability to effectively prepare and respond to the broad range of changes in a complex environment.

One possible approach to addressing liabilities of smallness and newness under complex environments is to carry multi-purpose resources that are useful in the face of a variety of environmental demands. The versatile nature of operational slack allows for it to be redeployed to face a range of situations (Hambrick 
and D'Aveni 1988). For instance, operational slack in the form of raw material and finished goods inventory has been shown to reduce the effects of demand- or supply-related shortages whether they are the result of supplier, raw materials, or internal production matters (Bozarth et al. 2009). Operational slack can also be applied quickly, ensuring continuity of production. For instance, operational slack can readily buffer the venture against unreliable supplier delivery or customer demand fluctuations.

Complex environments may also expose the venture to survival-enhancing opportunities (Bradley et al. 2011). Increased complexity has the implied potential for a venture to differentiate itself from its rivals (Simsek et al. 2007). Ventures with operational slack can more quickly deploy operational resources to create increasingly differentiated products and innovative operational processes (Azadegan 2011). Such advantages, however, are juxtaposed with the tradeoffs created by using operational slack in complex environments. Yet despite its possible negative effects, operational slack helps a venture to mitigate the ambiguities of a complex environment and to better position itself in exploiting possible opportunities through increased product differentiation, thereby increasing its chance of survival. Therefore:

Hypothesis 3 (H3): Environmental complexity moderates the relationship between operational slack and venture failure, such that with increasing operational slack at higher levels of environmental complexity the likelihood of venture failure is reduced.

\subsection{Environmental Munificence and Operational \\ Slack}

Low munificence (or hostility) refers to the scarcity of resources in the environment (Dess and Beard 1984). Given the inherent limitations of a hostile environment, responding to threats and opportunities has to be accomplished through lowered reliance on external exchange and increased reliance on the venture's internal capabilities (Castrogiovanni 1991). Venture literature has listed multiple methods for ventures to raise their independence and thereby augment their chances of survival in hostile environments. For instance, through "bricolage," ventures develop a culture to "make-do" or manage with obtainable resources (Baker and Nelson 2005). Bricolage helps the venture to better manage its resources, thereby warding off disruptions without the need for external help. A parallel stream on bootstrapping suggests that ventures can lessen their need for purchased equipment and limit their labor needs (Bhide 1992).

Bricolage and bootstrapping seem particularly useful for ventures operating in hostile environments; better management and lowered acquisition of resources can ensure that the venture sustains its business operation despite the unreliable nature of the hostile environment. Carrying operational slack acts in a similar vein by helping ventures manage resources more successfully, reducing the need for acquiring resources and therefore enabling them to operate with self-reliance. For instance, slack labor helps smooth scheduling and planning and thereby manages the venture's resources without external reliance. Similarly, capacity slack in the form of flexible machinery minimizes the need for acquiring (possibly unavailable) additional capacity when demand changes require it.

However, while self-reliance gained through operational slack can ensure business continuity, it can also carry trade-offs. Carrying reserve production capacity, or excess labor or materials, is likely to increase the venture's production costs and lower its profitability. Nevertheless, while there may be profit loss as a result of carrying operational slack, the alternative is to leave the venture exposed to threats in a hostile environment. Therefore:

Hypothesis 4 (H4): Environmental munificence moderates the relationship between operational slack and venture failure, such that with increasing operational slack at lower levels of environmental munificence the likelihood of venture failure is reduced.

\section{Methods}

\subsection{Data Description}

The sample used in this study consists of longitudinal data of new ventures registered in Sweden between 2000 and 2005 (both years inclusive). Swedish entrepreneurial activity extensively represents entrepreneurial activity in typical developed countries (Short et al. 2009). The database used to identify ventures was Affarsdata. Affarsdata compiles annual reports of Swedish ventures that are registered as $\mathrm{AB}$ (Aktiebolag or Aktiebolaget). A firm registered as an $A B$ could be publicly traded or privately held. In compliance with Swedish incorporation laws, privately held $\mathrm{ABs}$ must have capital of at least SEK 100,000 (US \$14,000) upon registration, and publicly held ABs must have at least SEK 500,000 (US $\$ 70,000$ ). To assess the role of operational slack on venture survival, we tracked ventures until the year 2009, during which time they could have failed or survived until 2009. In similar studies, ventures have typically been followed over a 5-year frame (e.g., Short et al. 2009).

The initial sample in Affarsdata showed that 93,489 firms were registered between the years 2000 and 
2005. To ensure that our sample represented young firms in the manufacturing sector, we removed firms from our sample if they met one or more of the following criteria: (i) firm was in a non-manufacturing sector, (ii) firm had more than 250 employees in the first year of incorporation, (iii) firm had no sales during the first 5 years, (iv) firm was not reporting sales in the first two years of its establishment, and (v) firm was publically held at time of registration. Specific to item (ii), it was important to eliminate those firms that started with a large resource base at incorporation. Such firms might have been firms registering under a different name (i.e., shell corporations). Therefore, firms with more than 250 employees at the time of incorporation could be such pre-existing and successful firms, yet could still be considered young if our sampling frame was strictly based on firm age (i.e., year of registration). Related to items (iii) and (iv), firms with no sales history were not likely to have existing operations and hence may not have helped assess the effect of operational slack. To ensure that operational history was adequately reflected, we eliminated firms with no sales in the first 2 years. In the analysis, we controlled for selection bias for firms with no sales in the first 5 years or firms not reporting sales in the first 2 years. Finally, related to item (v), Swedish firms with a starting capital greater than SEK 500,000 (US $\$ 70,000$ ) were considered large enough to be publicly traded. We removed those firms that started with a large resource base.

The resulting sample consisted of 3758 ventures registered between the years of 2000 and 2005, representing 119 unique 5-digit SIC codes in the manufacturing sector. We followed these ventures over a 10-year period (2000 to 2009). Of the 3758 ventures, 1604 of them did not survive, indicating a survival rate of $42.68 \%$. Such survival rates have been typical in venture studies (Headd 2003, Short et al. 2009). Detailed sample characteristics are provided in Table 1.

\subsection{Measures}

4.2.1. Venture Survival. We examined the influence of operational slack on venture survival across the observation period. Over the course of 10 years, 1604 ventures had failed (Table 1). The data provide the year and month of each venture's incorporation and year and month of each venture's termination. Using the timeframe of 1 month as the primary time unit, we tracked venture survival over a maximum of 120 months for ventures established in 2000, and a minimum of 60 months for ventures established in 2005. Unless stated otherwise, all independent variables, moderator variables, control variables, and self-selection variables are lagged at $(t-1)$ to assess their effects on venture survival at time $(t)$.

4.2.2. Operational Slack. We used three timevarying measures: (i) natural logarithm of industryadjusted ratio of annual sales to tangible assets, (ii) natural logarithm of industry-adjusted ratio of annual sales to labor, and (iii) natural logarithm of industry-adjusted days in inventory. These measures coincide with the definition of operational slack discussed earlier in the literature review (Caputo 1996, Hendricks et al. 2009). We first computed mean industry-level (based on 4-digit SIC codes) measures based on all firms' annual yearly performance reports. We then subtracted the industry mean of operational slack measures from firm-specific operational slack measures. Thus, we developed measures based on relative amount of operational slack vis-avis other firms in the industry. First, higher ln (sales to tangible assets) indicates lower capacity slack as fewer buffers are available in tasks, tools, and processes to meet environmental demands. Tangible assets are plant, machinery, and buildings reported in Swedish Krona. Sales to labor is the ratio of the natural $\log$ of sales and number of employees. Increased sales to labor indicates that limited slack labor is available for operational adjustments. Natural logarithm of days in inventory is a direct measure of inventory levels kept in reserve. Days in inventory are 365 times the ratio of the average of beginning and ending inventory to cost of goods sold.

4.2.3. Environmental Variables. We develop industry level time-varying measures from Affarsdata and the Swedish Business Register. Drawing on Dess and Beard (1984) and Keats and Hitt (1988), as recently used by Heeley et al. (2006), we operationalized dynamism, complexity, and munificence (conversely, environmental hostility) for each year with moving 5-year windows. ${ }^{1}$ Based on Keats and Hitt (1988) we used an OLS regression to measure munificence and dynamism. We started by identifying net sales and operating income in each of the 4-digit SIC codes represented in the sample. In the next step, two regressions were conducted: (i) natural logarithm of industry sales on time (5 years) and (ii) natural logarithm of operating income on time (5 years). We took the anti-log of each beta and used the average of betas as the measure of munificence. The measure of munificence is the average growth rate over a 5-year moving window. To ease interpretation we multiplied this measure by -1 to indicate that lower values signify increased munificence and higher values indicate increased hostility.

For the measure of environmental dynamism, we took anti-log of standard error of beta in each of the 


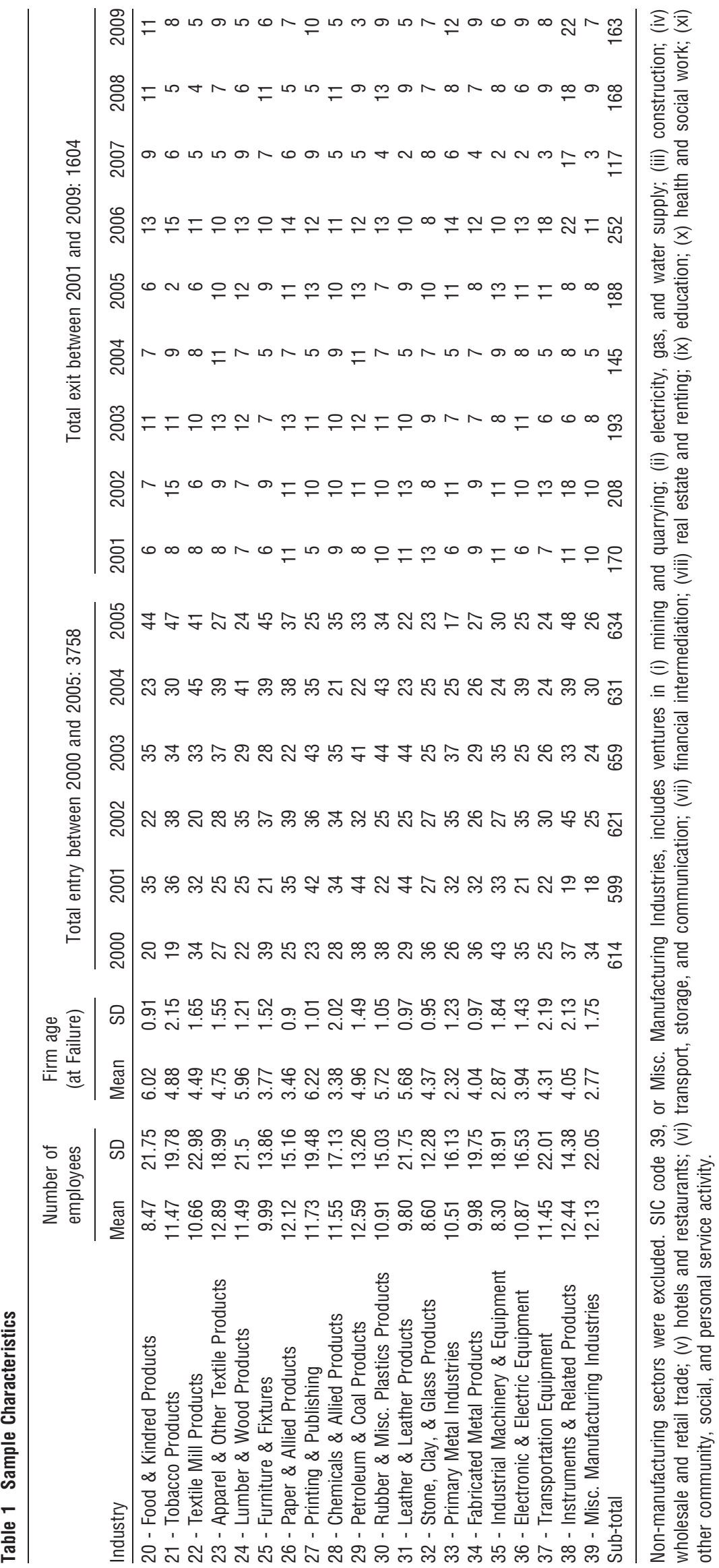


regressions used for measuring munificence. The average of the resulting standard error is the measure of environmental dynamism for a given year. Higher standard errors indicate discontinuities in the environment. The measure of environmental complexity is based on Grossack's (1965) index of dynamic concentration in a 4-digit SIC code. Environmental complexity is proxied as movement toward or away from large firm dominance in an industry. As the industry moves away from large firm dominance (i.e., lower concentration index), industry complexity increases. The measure of complexity is the regression coefficient of terminal year market shares of all firms (e.g., market shares of all firms in year 2000) on their shares in the initial year (e.g., market share of all firms in year 1996). The regression coefficient was obtained as $\beta=\sum x_{i} y_{i} / \sum x_{i}^{2}$ where $x_{i}$ and $y_{i}$ are deviations in market share from the mean. Under the original specification (Keats and Hitt 1988), complexity is reverse-scored; therefore, smaller numbers indicate more complex environments.

4.2.4 Controls. We used industry- and firmbased time-varying covariates as controls. Due to the secondary nature of the data used, several operational characteristics are unobservable, suggesting that operational slack may act as a proxy for other unobserved factors. Alternatively, industry-related factors could also affect many facets of unobserved venture characteristics. In operationalizing controls, firm-level measures were obtained from Affarsdata and industry-level measures were from the Swedish Business Register. We controlled for number of employees, operating cash flows, and percentage of owner equity for each year. Number of employees typically proxies for firm size. Ventures with a higher number of employees could face fewer liabilities of smallness and therefore might be more likely to survive for longer periods. In addition, a venture's larger size could also proxy for more formalized operational routines. With increasing firm size more formalization and control mechanisms are necessary to govern and manage firm activities. Greater size could also indicate a venture's greater viability in task environment and therefore an increased likelihood of survival. To control for time effects we used yearly time dummies. Operating cash flow could act as a proxy for liabilities of newness. Steady operating cash flow indicates consistency and reliability in a venture's input conversion routines. In addition, operating cash flow indicates venture ability to effectively engage in exchanges with stakeholders in the task environment.

Because entrepreneurs have better information about their venture's potential than outside stake- holders, adverse selection and moral hazard have been shown to be potential problems faced by investors (Arthurs et al. 2008). Problems of moral hazard are partly mitigated through higher equity, because the venture team is likely to work harder to enhance their residual returns. Therefore, we controlled for percent owner's equity. According to population ecology literature, industry conditions could play a critical role in venture survival. To control for industry conditions, we controlled for industry entry rate as the number of firms entering the industry each year. We measured the number of entries because new firm failure is more likely to occur in industries with a higher rate of entry than in industries with a lower rate of entry (Carroll and Hannan 2000, Caves 1998). According to resource partitioning theory, higher entry rates have indicated greater availability of resources and therefore lower levels of competition among existing firms. However, with lower entry rates there are fewer resources available, thereby resulting in more intense competition.

We further controlled for industry average firm size (natural log [total employees in the industry]/natural $\log$ [total number of firms]), industry sales growth rate from the previous year, and average firm age. To assess effects of time, we included a 12-month control band $(0-12,13-24,25-36,37-48,49$ 60 months and so on until 109-120 months). Higher industry average firm size indicates lower liability of smallness. Ventures short on resources are less likely to assemble a large resource base; therefore, when the average size of the firm is large, liabilities of smallness could further increase chances of failure. Older firms have more established routines and processes and are able to develop more effective responses than younger firms. Based on behavioral theory of the firm, year-to-year sales growth proxies for increased experimentation in the industry because more resources are available. Ventures in industries with greater sales growth are more likely to survive as increased experimentation at the industry level increases overall industry innovation.

Finally, the extent of dependence on upstream and downstream firms could lead to increased rent extraction by value chain stakeholders. More importantly, increased vertical relatedness limits degrees of freedom for ventures to develop capabilities that optimize their resource base. We drew on the Structural Analysis (STAN) database available from $\mathrm{OECD}^{2}$ to measure input-output relationships among different industries. Using the approach suggested by Fan and Lang (2000), and recently applied in operations management (Hendricks et al. 2009), we controlled for vertical relatedness. 
4.2.5. Controlling for Self-selection. We studied only ventures with reported sales in their year of inception. For example, ventures that had sales in 2005 may have possessed different underlying resources and capabilities than ventures that did not have sales in 2005. Also, firms that had sales in 2005 could have been endowed with more and better resources. Ignoring such initial conditions could bias estimations in favor of ventures with sales in the year of their inception. Furthermore, of the ventures that were not included, some may still have sales in the future. Venture capabilities may differ across these time period; therefore, we controlled for selection effects by including only ventures with sales in 2005 and assessing likelihood of failure.

Heckman (1979) proposed that selection bias could lead to overestimation when sampling is conducted on the outcome variable (i.e., in this study, venture failure). If only ventures with sales in the first year of incorporation are included in the sample, then such ventures are more likely to survive. Therefore, a sample could be biased toward ventures that are more likely to succeed. To reduce this bias, we used Heckman's two-step self-selection approach (Heckman 1979). Specifically, we used the inverse-Mill's ratio based on the two-step approach to control for self-selection of (i) ventures with no sales in 2000 and (ii) ventures with no sales between the years 2001 and 2009. Thus, by using two unique inverse-Mill's ratios we attempted to control for self-selection bias. For the first stage of the self-selection equation, we used the following factors to estimate the profit for each year: (i) number of patents filed, ${ }^{3}$ (ii) industry dummies (2-digit SIC codes), (iii) time dummies (year), (iv) total assets at venture registration, and (v) total equity of venture team. We then applied the estimated inverse-Mill's ratio as a control in our final model.

\subsection{Analytical Approach-Shared Frailty Weibull Regression}

This study employed a shared frailty Weibull regression survival analysis approach (Hanagal 2006, Mudholkar et al. 1996). While alternative approaches (such as panel data logistic regression) could have been used, such approaches do not accommodate censored outcomes and are more limited in their explanatory ability. ${ }^{4}$

4.3.1. Weibull Regression. A typical setting of survival analysis is observing whether a venture fails at time $t$. Some ventures may not fail during the observation period, in which case the observa- tion is censored. More specifically, if a venture failed during a given month in the 5-year period it is coded as 1; otherwise it is coded as 0 . If a venture survived the 5-year observation period, then its outcome is censored.

The indicator $\delta$ is used to indicate whether a venture failed at $t(\delta=1)$ or if it did not fail in the 120 -month time window $(\delta=0)$. The key criteria in modeling probability distribution of $t$ is the hazard function $h(t)$, which is the instantaneous likelihood of failure in month-year observation. The cumulative hazard function is $H(t)=\int_{0}^{t} h(s) \mathrm{d}$. A common model of $h(t)$ is Cox's proportional hazard model, where hazard rate is:

$$
h_{i}(t)=h_{0}(t) \mathrm{e}^{\left(\beta_{n} X_{n}+\beta_{0}\right)}, i=1,2,3, \ldots n .
$$

where $h_{0}(t)$ is the baseline function (common to all ventures), and $n$ predictors. A positive beta indicates increased likelihood of venture failure (because failure is coded as 1), and a negative beta indicates an increased likelihood of venture survival. However, in the above, $h_{i}(t)$ assumes a constant hazard rate. Here, such an assumption would mean that the likelihood of venture failure is the same in 2000 as in 2009. This is a questionable assumption as, due to the liability of newness and smallness, ventures are more likely to fail in early stages than later stages. Thus, the hazard rate for venture failure is much higher in early years than in later years. Our model does account for this. To accommodate the possibility of varying failure rates over the years of a venture's life, we use an accelerated failure time analysis. Specifically, we use the Weibull regression that allows flexible hazard function (Klein and Moeschberger 2003). Weibull distribution is specified as

$$
f\left(t_{i} ; z_{i}\right)=r \mathrm{e}^{\beta^{\prime} z_{i}} t_{i}^{r-1} \exp \left(-\mathrm{e}^{\beta^{\prime} z_{i}} t_{i}^{r}\right)
$$

where $t_{i}$ is the failure time of a venture with covariate vector $Z_{i}, \beta$ is vector of regression coefficients, and $r$ is the probability density function. This leads to baseline hazard function of $\lambda_{0}\left(t_{i}\right)=r t_{i}^{r-1}$.

If

$$
\mu_{i}=\mathrm{e}^{\beta^{\prime} z_{i}},
$$

then the parameterization is

$$
t_{i}=\operatorname{Weibull}\left(r, \mu_{i}\right),
$$

and the probability density function is

$$
\frac{\alpha}{\delta}\left(\frac{t}{\delta}\right)^{\alpha-1} \exp \left[-\left(\frac{t}{\delta}\right)^{\alpha}\right] t \geq 0
$$


where $\alpha(\alpha>0)$ is the shape parameter and $\delta(\alpha>0)$ is the scale parameter.

4.3.2. Shared Frailty. There are possibilities for two types of correlated errors in the analysis explained above: the venture's inception year and its industry can result in correlated errors. Ventures that started in a particular year share cohort effects and are more likely to be affected by founding conditions. Ventures in a given industry share common factors that affect the likelihood of their survival.

A potential approach could be using a fixed effects model with time and industry dummies. However, in survival analysis, fixed effects have been shown to lead to inconsistent standard errors (Box-Steffensmeier and De Boef 2006). As an alternative, we used a random effects model based on shared frailty. A widely used frailty model has been the gamma frailty model (Murphy 1995). Extending the Weibull regression equation, we derived

$$
h_{i}(t)=h_{0}(t) \mathrm{e}^{\left(\beta_{n} X_{n}+\beta_{0}\right)+W_{j} \psi}, i=1,2,3, \ldots n,
$$

where $W_{j}$ is a frailty term with probability distribution with mean 0 and standard deviation of 1 . When $\psi$ is statistically significant, then unobserved frailty is present in the sample.

Equation (3) contains gamma frailty in Weibull specification where $\theta$ is the frailty distribution specified as

$$
f\left(t_{i} ; z_{i}\right)=r \mathrm{e}^{\beta^{\prime} z_{i}} t_{i}^{r-1}\left[\exp \left(-\mathrm{e}^{\beta^{\prime} z_{i}} t_{i}^{r}\right)\right]^{\theta}
$$

\section{Results}

Table 2 provides the zero order correlation for the variables used in the analysis. Collinearity tests were conducted as part of robustness analyses. We tested for variance inflation factors (VIF), the highest of which was 3.06 for days in inventory. The recommended cut-off for VIF is 4.0 (Van den Poel and Larivière 2004).

Table 3 provides the results of our regression analyses to predict new venture failure. Moderation effects in survival analysis require including the time scale, independent effects, and interaction effects. Therefore, traditional OLS-based interaction analyses are not feasible in survival analysis. We plotted moderation effects based on $+1 \mathrm{SD}$ and $-1 \mathrm{SD}$ of independent variables, and hazard rate effects at high and low values of environmental dynamism, environmental complexity, or environmental hostility. For industry-adjusted ratio of sales to property, plant, and equipment in Figure 1a, equation (4) is specified as:

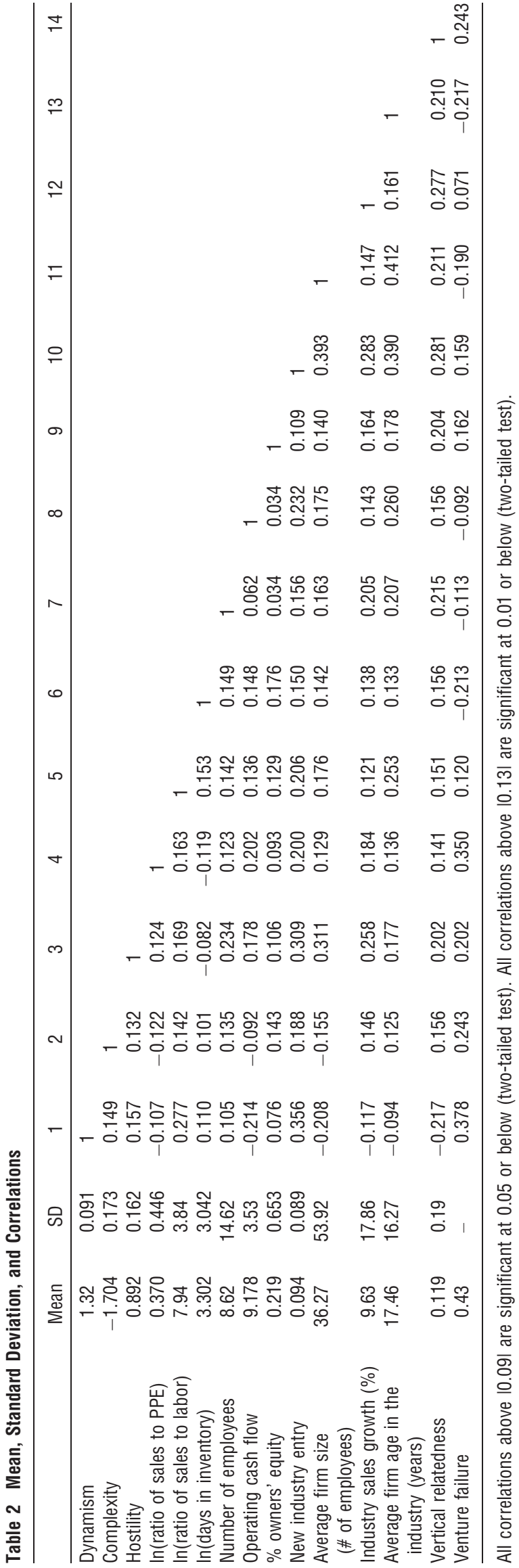




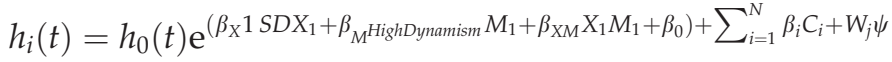

$$
\begin{aligned}
& h_{i}(t)=h_{0}(t) \mathrm{e}^{\left(\beta_{X} 1 S D X_{1}+\beta_{M} \text { AverageDynamism } M_{1}+\beta_{X M} X_{1} M_{1}+\beta_{0}\right)+\sum_{i=1}^{N} \beta_{i} C_{i}+W_{j} \psi} \\
& h_{i}(t)=h_{0}(t) \mathrm{e}^{\left(\beta_{X} 1 S D X_{1}+\beta_{M^{L o w D y n a m i s m}} M_{1}+\beta_{X M} X_{1} M_{1}+\beta_{0}\right)+\sum_{i=1}^{N} \beta_{i} C_{i}+W_{j} \psi}
\end{aligned}
$$

\begin{tabular}{|c|c|c|c|c|c|c|}
\hline & \multicolumn{2}{|c|}{ Model 1 controls } & \multicolumn{2}{|c|}{ Model 2 direct effects } & \multicolumn{2}{|c|}{$\begin{array}{c}\text { Model } 3 \text { moderating } \\
\text { effects }\end{array}$} \\
\hline & $\beta$ & se & $\beta$ & se & $\beta$ & se \\
\hline \multicolumn{7}{|l|}{ Environmental Factors } \\
\hline Environmental dynamism & & & $0.430^{* \star \star}$ & $(0.079)$ & $0.358^{* * *}$ & $(0.121)$ \\
\hline Environmental complexity & & & $0.252^{* \star *}$ & $(0.088)$ & $0.235^{\star * \star}$ & (0.091) \\
\hline Environmental hostility & & & $0.210^{\star * \star}$ & $(0.074)$ & $0.196^{\star * \star}$ & (0.072) \\
\hline \multicolumn{7}{|l|}{ Controls } \\
\hline Number of employees & -0.115 & $(0.103)$ & -0.105 & $(0.092)$ & -0.091 & $(0.089)$ \\
\hline$\%$ owners' equity & -0.095 & $(0.117)$ & -0.083 & $(0.097)$ & -0.085 & $0.096)$ \\
\hline Operating cash flow & $-0.244^{\star \star}$ & $(0.111)$ & $-0.220^{\star \star}$ & $(0.115)$ & $-0.201^{\star *}$ & $(0.084)$ \\
\hline New industry entry & $0.152^{* \star}$ & $(0.070)$ & $0.143^{* *}$ & $(0.066)$ & $0.141^{* *}$ & $(0.061)$ \\
\hline Average firm size & $0.164^{\star}$ & $(0.081)$ & $0.169^{*}$ & $(0.074)$ & $0.152^{\star}$ & (0.068) \\
\hline Industry sales growth & $-0.205^{\star}$ & $(0.098)$ & $-0.196^{*}$ & $(0.089)$ & $-0.182^{*}$ & $(0.074)$ \\
\hline Average firm age & 0.074 & $(0.076)$ & 0.062 & $(0.069)$ & 0.069 & $(0.063)$ \\
\hline Vertical relatedness & $0.286^{\star \star}$ & $(0.093)$ & $0.264^{* \star}$ & $(0.104)$ & $0.239^{\star \star \star}$ & $(0.101)$ \\
\hline \multicolumn{7}{|l|}{ Time Dummies } \\
\hline 2000 [0-12 months] & $-0.130^{\star \star \star}$ & $(0.047)$ & $-0.143^{\star *}$ & $(0.034)$ & $-0.137^{\star \star \star}$ & $(0.033)$ \\
\hline 2001 [13-24 months] & $-0.115^{\star}$ & $(0.059)$ & $-0.103^{\star \star}$ & $(0.047)$ & $-0.098^{\star \star}$ & $(0.054)$ \\
\hline 2002 [25-36 months] & -0.058 & $(0.068)$ & -0.055 & $(0.055)$ & -0.046 & $(0.057)$ \\
\hline 2003 [37-48 months] & 0.082 & $(0.050)$ & $0.066^{*}$ & $(0.038)$ & $0.063^{*}$ & $(0.032)$ \\
\hline 2004 [49-60 months] & $0.153^{\star \star \star}$ & $(0.048)$ & $0.135^{\star \star \star}$ & $(0.037)$ & $0.140^{\star \star \star}$ & $(0.033)$ \\
\hline 2005 [61-72 months] & $0.159^{\star \star \star}$ & $(0.065)$ & $0.140^{* \star *}$ & $(0.058)$ & $0.137^{\star \star \star}$ & $(0.056)$ \\
\hline 2006 [73-84 months] & $0.173^{\star \star \star}$ & $(0.062)$ & $0.155^{* \star *}$ & $(0.046)$ & $0.159^{\star * \star}$ & $(0.040)$ \\
\hline 2007 [85-96 months] & $0.083^{\star}$ & $(0.047)$ & $0.070^{* *}$ & $(0.032)$ & $0.066^{\star *}$ & (0.029) \\
\hline 2008 [97-108 months] & 0.055 & $(0.069)$ & 0.135 & $(0.099)$ & 0.042 & $(0.032)$ \\
\hline 2009 [109-120 months] & 0.035 & $(0.048)$ & 0.017 & $(0.037)$ & 0.017 & $(0.037)$ \\
\hline Intercept & $0.051^{\star \star \star}$ & $(0.022)$ & $0.046^{\star \star \star}$ & $(0.042)$ & $0.040^{\star \star \star}$ & $(0.019)$ \\
\hline \multicolumn{7}{|l|}{ Operational Slack [H1] } \\
\hline In(ratio of sales to PPE) & & & $0.307^{\star \star \star}$ & $(0.132)$ & $0.286^{\star \star \star}$ & $(0.115)$ \\
\hline In(ratio of sales to labor) & & & $0.104^{\star}$ & $(0.052)$ & $0.093^{\star}$ & $(0.042)$ \\
\hline In(days in inventory) & & & $-0.176^{*}$ & $(0.081)$ & $-0.152^{*}$ & $(0.071)$ \\
\hline \multicolumn{7}{|l|}{ Two-way Interactions_Environmental Dynamism [H2] } \\
\hline Environmental dynamism $\times \operatorname{In}$ (ratio of sales to PPE) [H2] & & & & & $0.143^{\star}$ & $(0.069)$ \\
\hline Environmental dynamism $\times \ln$ (ratio of sales to labor) & & & & & $0.147^{\star}$ & $(0.071)$ \\
\hline Environmental dynamism $\times \operatorname{In}$ (days in inventory) & & & & & $-0.123^{*}$ & $(0.062)$ \\
\hline \multicolumn{7}{|l|}{ Two-way Interactions_Environmental Complexity [H3] } \\
\hline Environmental complexity $\times \operatorname{In}($ ratio of sales to PPE) [H3] & & & & & $0.159^{\star}$ & $(0.079)$ \\
\hline Environmental complexity $\times \operatorname{In}$ (ratio of sales to labor) & & & & & $0.109^{*}$ & $(0.051)$ \\
\hline Environmental complexity $\times \ln$ (days in inventory) & & & & & $-0.104^{*}$ & $(0.053)$ \\
\hline \multicolumn{7}{|l|}{ Two-way Interactions - Environmental Hostility [H4] } \\
\hline Environmental hostility $\times \operatorname{In}$ (ratio of sales to PPE) [H4] & & & & & $0.092^{*}$ & $(0.044)$ \\
\hline Environmental hostility $\times \ln$ (ratio of sales to labor) & & & & & $0.126^{*}$ & $(0.062)$ \\
\hline Environmental hostility $\times \ln$ (days in inventory) & & & & & $-0.109^{\star}$ & $(0.049)$ \\
\hline \multicolumn{7}{|l|}{ Selection Bias } \\
\hline Mill's-ratio sales & $-0.404^{\star \star}$ & $(0.153)$ & $-0.322^{* *}$ & $(0.143)$ & $-0.346^{\star *}$ & $(0.117)$ \\
\hline Mill's-ratio sale 2000-2009 & $-0.224^{\star}$ & $(0.100)$ & $-0.256^{\star *}$ & $(0.121)$ & $-0.207^{\star *}$ & $(0.119)$ \\
\hline AIC & 2753.304 & & 2372.405 & & 1907.304 & \\
\hline Weibull Shape Parameter & 0.629 & & 0.564 & & 0.509 & \\
\hline Frailty Parameter & $0.518^{\star \star \star}$ & & $0.522^{\text {*** }}$ & & $0.492^{\star \star \star}$ & \\
\hline Wald- $\chi^{2}(\mathrm{df})$ & 1270.834 & & 1359.305 & & 1490.768 & \\
\hline Change in Wald- $\chi^{2}$ test & & & $88.741(6)^{\star * *}$ & & $131.463(9)^{* \star *}$ & \\
\hline
\end{tabular}

Table 3 Shared Gamma Frailty Weibull Model (Failed Ventures $=1$ )

${ }^{*} p<0.05 ;{ }^{* *} p<0.01 ;{ }^{* *} p<0.001$. To ease interpretation, we (i) multiply dynamism by -1 so that higher values show higher dynamism and (ii) multiply munificence by -1 so that higher values show higher hostility/lower munificence. 
Figure 1 Hypothesis 2 - Moderation Effects of Environmental Dynamism at (a) +1 SD Ratio of Property, Plant, and Equipment; (b) -1 SD Ratio of Property, Plant, and Equipment; (c) +1 SD Labor Productivity; (d) -1 SD Labor Productivity; (e) +1 SD Days in Inventory; (f) -1 SD Days in Inventory

(a)

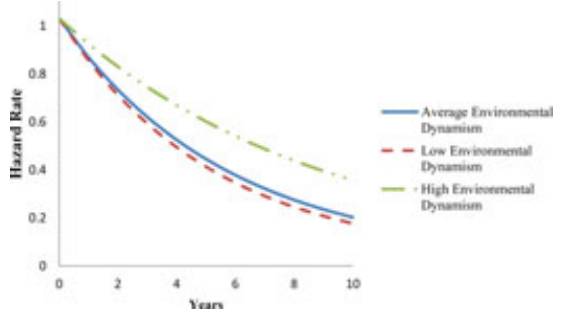

(c)

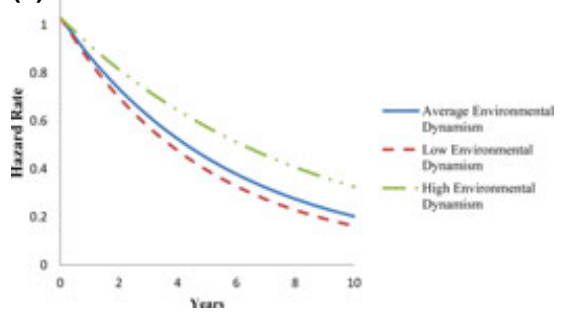

(e)

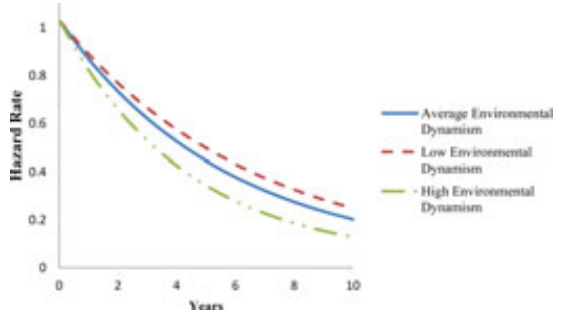

(b)

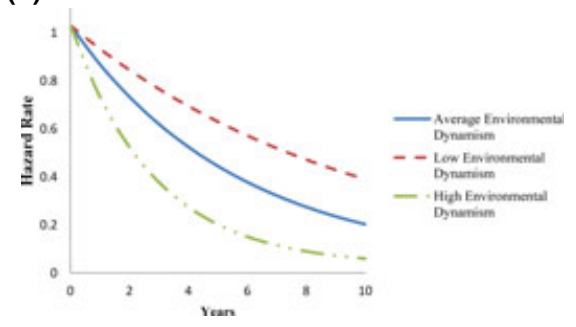

(d)

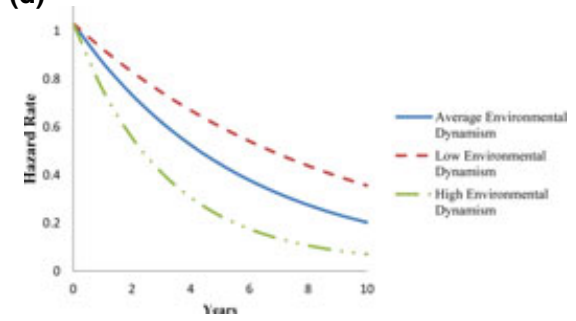

(f)

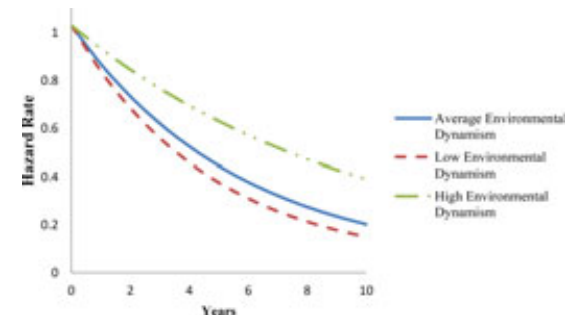

where $X$ is +1 SD industry-adjusted ratio of sales to property, plant, and equipment; $M$ represents high and low levels of environmental dynamism; and $C$ represents the remaining independent variables, moderation effects, and control variables. The $x$-axis represents hazard rates. Steeper curves indicate a higher hazard rate (or, failure likelihood). Flatter curves indicate a relatively lower hazard likelihood. In addition, at a given time, coordinates with higher values indicate greater likelihood of failure; coordinates with lower values indicate lower likelihood of failure. We used a similar approach in equation (4) to plot the remaining moderation effects shown in Figures 1-3.

Hypothesis 1 proposed that operational slack reduces the likelihood of venture failure. For ratio of sales to tangible assets (lower values indicate higher capacity slack), results indicate that a higher ratio of sales to tangible assets $(\beta=0.286 ; p<0.001)$ increases the likelihood of venture failure. Increased sales per labor (with $\beta=0.093 ; p<0.05$ indicating lower levels of labor slack) leads to increased likelihood of venture failure. Higher levels of days in inventory (with $\beta=-0.152 ; p<0.05$ indicating higher levels of inven- tory slack) decreases the chance of venture failure. These results confirm the theoretical arguments made in Hypothesis 1. Buffered and redundant production capacity reduces the effects of internal mistakes and external events on the venture's production. Similarly, labor and inventory slack provide better flexibility in the venture's management of its operations, thereby ensuring that threats are less damaging to the young venture. Each of the three forms of operational slack ensures business continuity, thus lowering the chances of failure.

Hypothesis 2 proposed that with increasing environmental dynamism, higher slack leads to a lower likelihood of failure. Results show that lower capacity slack (or $\beta=0.143 ; p<0.05$ showing a higher ratio of sales to tangible assets) and lower labor slack (or $\beta=0.147 ; p<0.05$ showing higher sales to labor) lead to an increased likelihood of venture failure. Conditional hazard rates under moderation effects are provided in Figure 1.

As shown in Figure 1b, under higher capacity slack (-1 SD of ratio of sales to property, plant, and machinery) the hazard rate is lower at higher levels of environmental dynamism, whereas under lower 
Figure 2 Hypothesis 3 - Moderation Effects of Environmental Complexity at (a)+1 SD Ratio of Property, Plant, and Equipment; (b) -1 SD Ratio of Property, Plant, and Equipment; (c) +1 SD Labor Productivity; (d) -1 SD Labor Productivity; (e) +1 SD Days in Inventory; (f) -1 SD Days in Inventory

(a)

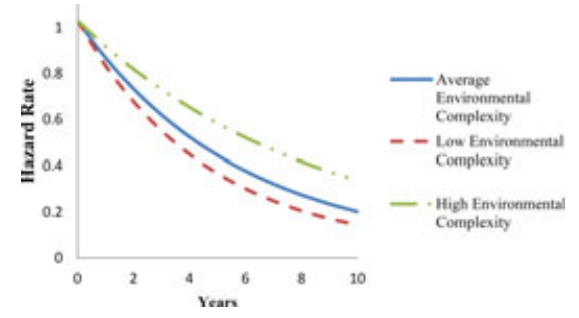

(c)

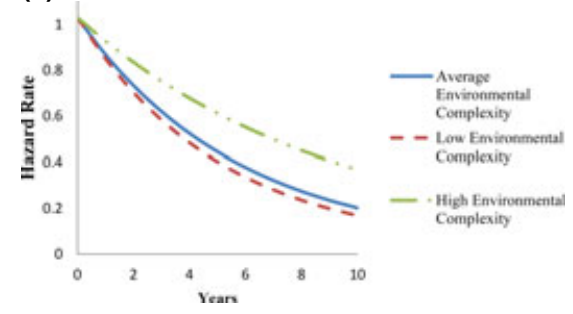

(e)

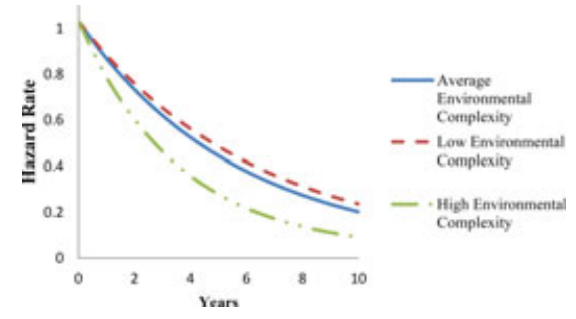

(b)

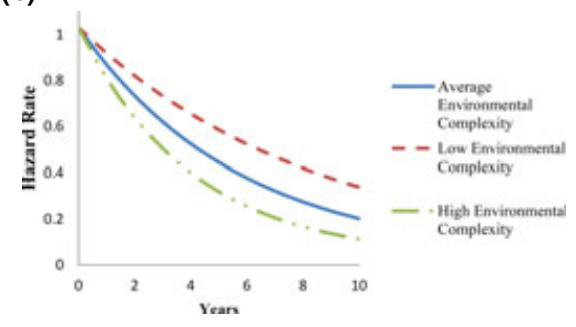

(d)

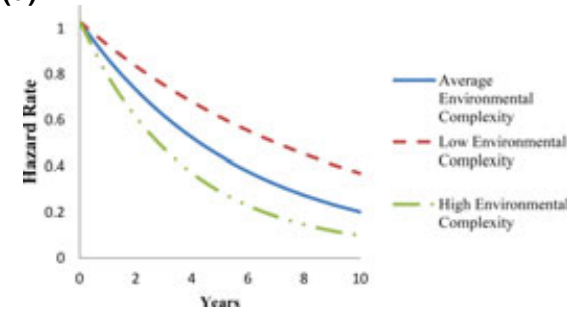

(f)

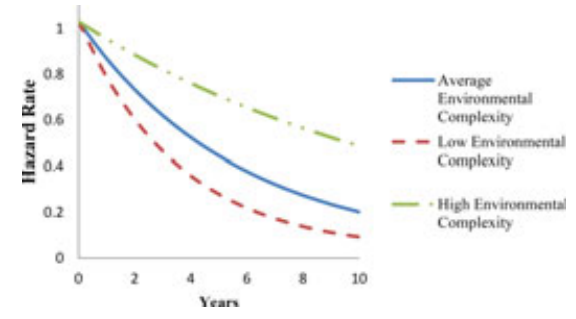

capacity slack (+1 SD of ratio of sales to property, plant, and machinery) the hazard rate is greater at higher levels of environmental dynamism (see Figure 1a). Similar effects are observed for labor productivity in Figure 1c and d. Furthermore, increased inventory slack (increased days in inventory) reduces the chances of venture failure $(\beta=-0.123 ; p<0.05)$. Figure 1e shows that at more days in inventory (-1 SD, or greater inventory slack), the hazard rate is lower under greater environmental dynamism. As shown in Figure 1f, at higher lower levels of days in inventory or lower inventory slack, the hazard rate is greater under higher environmental dynamism. Similar interpretations are applicable to the moderation effects of environmental complexity and environmental hostility.

Hypothesis 3 proposed the moderating effects of operational slack under environmental complexity. Results show that reduced operational slack, resulting from reduced capacity slack $(\beta=0.159 ; p<0.05)$ and reduced labor slack $(\beta=0.109 ; p<0.05)$, increases the likelihood of venture failure. Similarly, increased inventory slack $(\beta=-0.104 ; p<0.01)$ reduces the likelihood of venture failure. As shown in Figure 2, for ventures operating under higher environmental complexity, increasing capacity slack, labor slack, and inventory slack lead to lower hazard rates.

Hypothesis 4 proposed that higher operational slack leads to lower likelihood of failure under increased environmental hostility. Results show that lower capacity slack $(\beta=0.092 ; p<0.05)$ and lower labor slack $(\beta=0.126 ; p<0.05)$ increase the likelihood of failure. Higher inventory slack leads to a lower likelihood of venture failure $(\beta=-0.109$; $p<0.05)$. Results shown in Figure 3 further confirm this hypothesis.

The results for all three moderating hypotheses (H2, H3, and H4) show a consistent pattern across all three contexts of the effects of operational slack on venture survival. As the levels of environmental dynamism, complexity, and hostility are increased, operational slack lowers the likelihood of venture failure. These findings support the theoretical arguments posed earlier. Operational slack - in the form of capacity slack, labor slack, or inventory slackhelps reduce interruptions and ensures continuity in operations, particularly in challenging settings. Carrying operational slack in any of its three forms provides a venture with more redundant and flexible options to face unforeseen environmental change 
Figure 3 Hypothesis 4 - Moderation Effects of Environmental Hostility at (a) +1 SD Ratio of Property, Plant, and Equipment; (b) -1 SD Ratio of Property, Plant, and Equipment; (c) +1 SD Labor Productivity; (d) -1 SD Labor Productivity; (e) +1 SD Days in Inventory; (f) -1 SD Days in Inventory.

(a)

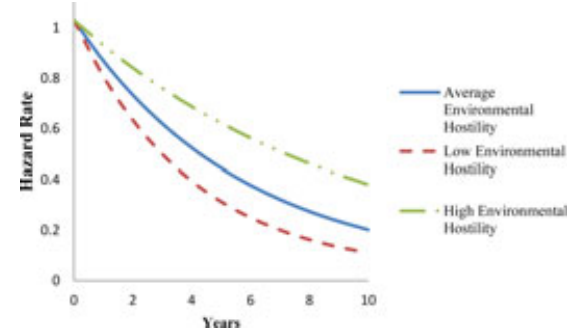

(c)

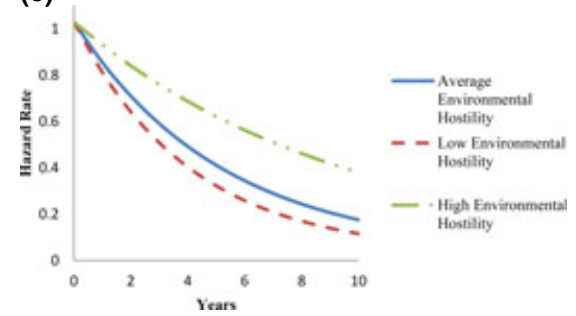

(e)

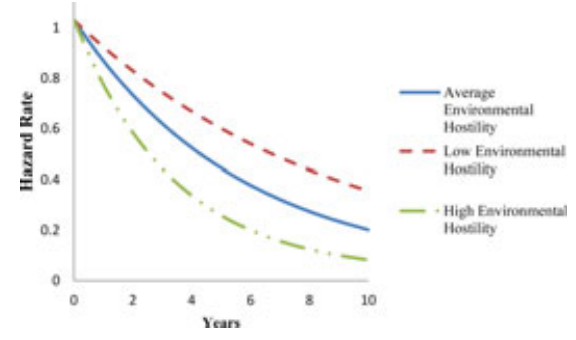

(b)

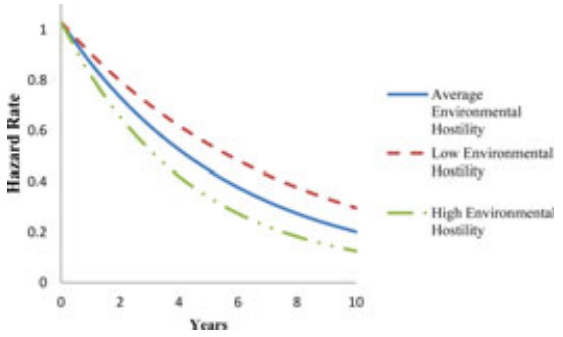

(d)

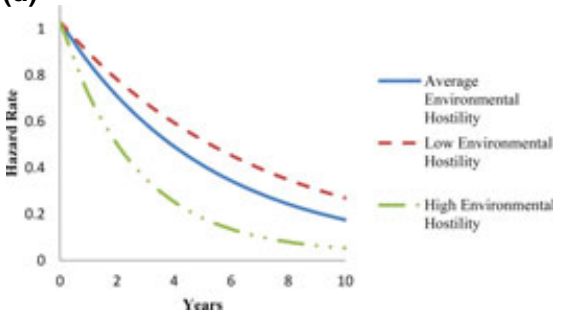

(f)

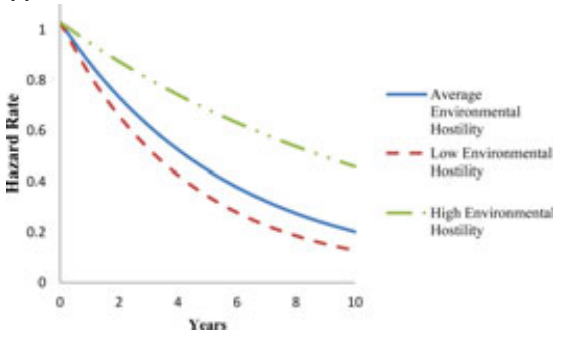

and capitalize on rising opportunities. In turn, this ability enhances the venture's resiliency and reduces its chance of failure.

\subsection{Robustness Tests}

Five separate robustness analyses were conducted to further validate the above findings. (Results are available in the Online Supplement.) These tests support the robustness of the model and findings. Following Efron and Tibshirani (1993), we calculated power using the bootstrapping approach by drawing 1000 replications. The power for the model was 0.88 . This power analysis shows that our models were well above the statistically prescribed levels (Cohen et al. 2002). We further assessed whether moderation effects hold under individual specification of interaction effects, and whether overall model specification was significant for individual hypotheses. We found that individual interaction models were significant.

It may be possible that the dynamics of the liability of smallness could vary among firms with different numbers of employees. To test for heterogeneity in effects due to differences in firm size, we split the

sample into the following sample pairs: (i) $-1 \sigma$ vs. the rest of the sample, (ii) $-2 \sigma$ vs. the rest of the sample, (iii) $+1 \sigma$ vs. the rest of the sample, and (iv) $+2 \sigma$ vs. the rest of the sample. Although the inferences did not change, we did observe that the effects were stronger for the smaller sized firm sub-groups. Thus, even though the overall inferences did not change, we observe that operational slack effects are stronger for smaller ventures.

We also assessed whether the effects obtained were curvilinear for operational slack and firm survival. Although no direct empirical or theoretical evidence exists to suggest a non-linear relationship, financial measures of slack have been shown to have an inverted U-shaped relationship to slack (Piccolo et al. 2008). While slack has buffered ventures from environmental changes (Cyert and March 1963, Thompson 1967), at higher levels it can be costly and can generate strategic mismatch (Litschert and Bonham 1978). To test if such effects exist for operational slack we controlled for non-linear effects of the three measures of operational slack. The quadratic forms of direct effects and moderating effects were insignificant. Therefore, operational slack and 
operational profitability have increasing returns. We also tested to see if interaction effects among the operational slack variables were significant. None were significant.

To test the robustness of the piecewise Weibull model, we ran other possible survival distributions under accelerated failure time models, specifically the generalized-gamma, log-logistic, and log-normal distributions. The Weibull model presented in this paper provided the best fit (based on AIC); however, the results are not qualitatively different from the alternative distributions.

Finally, although our theoretical propositions suggested that managing slack is critical to venture survival, we do not propose overlooking profitability. An indirect control for profitability in a model has been measuring operating cash flows. While operating cash flows can be used as a control for flow of resources in the venture, venture performance could also have impact on firm survival. To ascertain whether management of operational slack is not confounded with underlying profitability, we assessed whether our results differ when profitability measures (return on sales, return on assets, return on equity) were controlled for. The results show no significant difference in direction, magnitude, and significance relationships as proposed in Hypotheses 1 through 4 .

\section{Discussions and Conclusions}

We investigated the role of operational slack in venture survival under increased dynamism and complexity and decreased munificence. We hypothesized that the versatility and quickness in redeployment offered by operational slack allows a venture to face threats and leverage opportunities in its environment more quickly, more effectively, and with more self-reliance, thus reducing the likelihood of the venture's failure. Empirical results confirm that operational slack-in the forms of reserve production capacity, excess labor, or available inventoryenhance venture survival when operating under these "tough" contexts.

At face value, these results may suggest that firms with lower efficiency of operations (i.e., lower asset utilization, lower labor productivity, and higher inventory levels) perform better than those with higher efficiency. We provided three particular reasons to place these findings into proper perspective. First, the subject of analysis involved venture firms in the early stages of their lifecycle. Such firms may not have had time to develop efficient operating practices. Given these firms' nascent state, an assessment based on efficiency measures may not be properly reflective of their performance. Second, the context of this anal- ysis was in "tough" environmental settings, where the implementation and use of efficiency-related practices may prove to be challenging. As has been heavily explored, a lowering of operational slack (i.e., through the use of techniques related to lean manufacturing, for instance), may help asset utilization for typical organizations operating in ordinary circumstances. However, such a prospect seems less viable for increasing the chances of venture survival while operating in challenging environments.

Unlike previous studies of organizational slack (e.g., Tan and Peng 2003), we did not find a curvilinear relationship between increased operational slack and venture survival. The common argument made in support of curvilinear relationships is that beyond a certain point, organizational slack invites complacency (George 2005). Whether the notion of complacency can be applied to this context may be questioned, as this study assessed survival instead of financial profitability. While higher operational slack may cause lower profitability, the added buffer ensures that the venture does not face bankruptcy and it continues to "live another day." These findings align with what has been theorized as the benefits (and trade-offs) of applying risk reduction strategies by ventures (Shepherd et al. 2000). Also, a recent study by Voss et al. (2008) evaluated the interaction effect between operational slack and environmental threats and did not find significance in the relationship. Voss et al. (2008) were concerned with the effects of operational slack on innovation performance. As our dependent variable is venture survival, their findings neither confirm nor contradict ours. ${ }^{5}$

Our findings should be of value from several angles to researchers in the operations management, entrepreneurship, and organizational management fields. First, our results highlight the importance of a less emphasized form of slack, namely that of operational slack, in protecting venture firms from the influence of external uncertainties. The role of operational slack in different stages of a firm's lifecycle, and its interaction with environmental factors, seem to be an unexplored area of research. Second, this study distinguished between operational slack and other types of organizational slack. It also defined and detailed the characteristics of operational slack. Specific to organizational management literature, operational slack has been traditionally categorized as absorbed slack (Singh 1986). However, in measuring absorbed slack, most studies have relied on accounting measures other than those related to operational matters such as selling, general, and administrative expenses (SG\&A). We defined and distinguished operational slack based on measures more reflective of the characteristics of a firm's operation. Third, from an 
entrepreneurship perspective our work focused on the role of operational slack as it relates to venture success, an aspect that has not been highlighted in the literature. As recently noted by Kickul et al. (2011), investigating the effects of operational slack on venture survival is a timely and relevant topic of research opportunity.

Two managerially relevant implications seem important to note. One is the need for distancing the concept of operational slack as a manifest of systemic "waste," particularly for ventures. The second is a natural tendency of entrepreneurs to endure short-term sacrifices and tolerate an inadequacy of resources in the hopes of future prosperity. Many entrepreneurs take pride in "doing more with less." Such strong preconceptions can sway the venture away from carrying adequate resources to effectively and reliably manage its operations, particularly in tough environmental settings. In this study we highlighted how venture survival may require side-stepping the negative connotations associated with operational slack. Another important insight is the need for ventures to fully recognize their operating environment and their operating resources. Being familiar with the nature of the risks inherent in one's operating context, and recognizing how to leverage the venture's operating capabilities can be used to ward off imminent possibilities of extinction.

\section{Limitations and Future Research}

This study carries some expected limitations. First, although we considered the longitudinal effects of operational slack on venture survival, it is possible that such effects can vary during different stages of a venture's life. As firms progress through emergent, early, and later stages of growth, their resource needs also change. Future researchers may consider assessing the effect of operational slack across different stages of venture firm growth. Second, ventures are not all the same in terms of their internal capabilities and may carry varied foci and strategies. However, our analysis did not consider the varying possible operational capabilities such as a venture's manufacturing flexibility or its operational agility in managing disruptions. Inclusion of such variables could enhance findings of future research. Lastly, slack can take many forms, some of which may be more versatile while others may be more effective in addressing particular issues. Given the characteristic differences among the different forms of slack, ventures may have to make trade-offs when deciding which type to use. Such trade-offs may even be apparent between different variations of operational slack. Future work may consider evaluating the effects of capacity slack, human resource slack, and inventory slack on venture survival.

\section{Notes}

${ }^{1}$ For example, to measure environmental variables for the year 2000, we used a 5-year time window from 1996 to 2000; for the year 2001 we used a 5-year time window from 1997 to 2001, and so on. These moving 5-year windows were used for each of the time-varying measures of dynamism, complexity, and munificence.

${ }^{2}$ http://stats.oecd.org/

${ }^{3}$ This data is from the European Patent Office and was crossreferenced with the Swedish Patent and Registration Office.

${ }^{4}$ Detailed exposition of the comparative advantages of survival analysis is beyond the scope of this work, we refer interested readers to Hanagal (1992) for deeper exposition regarding the accommodation of censored outcomes.

${ }^{5}$ We appreciated the reference to the work and results reported by Voss et al. (2008) by the anonymous POM reviewer.

\section{References}

Adler, P. S., M. Benner, D. J. Brunner, J. P. MacDuffie, E. Osono, B. R. Staats, H. Takeuchi, M. L. Tushman, S. G. Winter. 2009. Perspectives on the productivity dilemma. J. Oper. Manag. 27 (2): 99-103.

AhmadBeygi, S., A. Cohn, M. Lapp. 2010. Decreasing airline delay propagation by re-allocating scheduled slack. IIE Trans. 42(7): 478-489.

Anand, G., P. Ward. 2004. Fit, flexibility and performance in manufacturing: Coping with dynamic environments. Prod. Oper. Manag. 13(4): 369-385.

Anupindi, R., R. Akella. 1993. Diversification under supply uncertainty. Manage. Sci. 39(8): 944-963.

Arthurs, J. D., R. E. Hoskisson, L. W. Busenitz, R. A. Johnson. 2008. Managerial agents watching other agents: Multiple agency conflicts regarding underpricing in IPO firms. Acad. Manag. J. 51(2): 277-294.

Atwater, J. B., S. S. Chakravorty. 2002. A study of the utilization of capacity constrained resources in drum-buffer-rope systems. Prod. Oper. Manag. 11(2): 259-273.

Atwater, J. B., A. A. Stephens, S. S. Chakravorty. 2004. Impact of scheduling free goods on the throughput performance of a manufacturing operation. Int. J. Prod. Res. 42(23): 4849-4869.

Azadegan, A. 2011. Benefiting from supplier operational innovativeness: The influence of supplier evaluations and absorptive capacity. J. Suppl. Chain Manag. 42(2): 49-64.

Azadegan, A., K. Dooley. 2010. Supplier innovativeness, organizational learning styles and manufacturer performance: An empirical assessment. J. of Oper. Manag. 28(6): 488-505.

Baker, T., R. Nelson. 2005. Creating something from nothing: Resource construction through entrepreneurial bricolage. Adm. Sci. Q. 50(3): 329-366.

Bartezzaghi, E., R. Verganti. 1995. Managing demand uncertainty through order overplanning. Int. J. Prod. Econ. 40(2-3): 107-120.

Baum, J., B. Bird. 2010. The successful intelligence of high-growth entrepreneurs: Links to new venture growth. Organ. Sci. 21(2): 397-412.

Bhide, A. 1992. Bootstrap finance: The art of start-ups. Harvard Bus. Rev. 70(6): 109-117.

Bode, C., S. M. Wagner, K. J. Petersen, L. M. Ellram. 2011. Understanding responses to supply chain disruptions: Insights from 
information processing and resource dependence perspectives. Acad. Manag. J. 54(4): 833-854.

Bourgeois, L. I.. 1981. On the measurement of organizational slack. Acad. Manag. Rev. 6(1): 29-39.

Bourland, K. E., C. A. Yano. 1994. The strategic use of capacity slack in the economic lot scheduling problem with random demand. Manage. Sci. 40(12): 1690-1704.

Box-Steffensmeier, J. M., S. De Boef. 2006. Repeated events survival models: The conditional frailty model. Stat. Med. 25(20): 3518-3533.

Bozarth, C. C., D. P. Warsing, B. B. Flynn, E. J. Flynn. 2009. The impact of supply chain complexity on manufacturing plant performance. J. Oper. Manag. 27(1): 78-93.

Bradley, S. W., H. Aldrich, D. A. Shepherd, J. Wiklund. 2010. Resources, environmental change, and survival: Asymmetric paths of young independent and subsidiary organizations. Strat. Manag. J. 32(5): 486-509.

Bradley, S. W., D. A. Shepherd, J. Wiklund. 2011. The importance of slack for new organizations facing "tough" environments. J. Manag. Stud. 48(5): 1071-1097.

Bruderl, J., R. Schussler. 1990. Organizational mortality - The liabilities of newness and adolesence. Adm. Sci. Q. 35(3): 530-547.

Brush, C. G., P. G. Greene, M. M. Hart. 2001. From initial idea to unique advantage: The entrepreneurial challenge of constructing a resource base. Acad. Manag. Exec. 15(1): 64-78.

Caputo, M. 1996. Uncertainty, flexibility and buffers in the management of the firm operating system. Prod. Plan. Control 7(5): 518-528.

Carroll, G. 1983. A stochastic model of organizational mortality: Review and reanalysis. Soc. Sci. Res. 12(4): 309-329.

Carroll, G., M. Hannan. 2000. Why corporate demography matters: Policy implications of organizational diversity. Calif. Manag. Rev. 42(3): 148-163.

Castrogiovanni, G. 1991. Environmental munificence: A theoretical assessment. Acad. Manag. Rev. 16(3): 542-565.

Caves, R. 1998. Industrial organization and new findings on the turnover and mobility of firms. J. Econ. Lit. 36(4): 1947-1982.

Child, J. 1972. Organizational structure, environment and performance, the role of strategic choice. Sociology 6(1): 1-22.

Chopra, S., M. S. Sodhi. 2004. Managing risk to avoid supplychain breakdown. Sloan Manag. Rev. 46(Fall): 53-61.

Cohen, J., P. Cohen, S. G. West, L. S. Aiken. 2002. Applied Multiple Regression/Correlation Analysis for the Behavioral Sciences. 3rd edn. Lawrence Erlbaum, Mahwah, NJ.

Cyert, R., J. March. 1963. A Behavioral Theory of the Firm. PrenticeHall, Englewood Cliffs, NJ.

De Carolis, D., Y. Yang, D. Deeds. 2009. Weathering the storm: Preparing new ventures for an adverse event. Strat. Entrepreneurship J. 3(2): 147-160.

Dess, G., D. Beard. 1984. Dimensions of organizational task environments. Adm. Sci. Q. 29(1): 52-73.

Efron, B., R. J. Tibshirani. 1993. An Introduction to the Bootstrap. Chapman \& Hall, Boca Raton, FL.

Esteve-Perez, S., J. A. Manez-Castillejo. 2008. The resource-based theory of the firm and firm survival. Small Bus. Econ. 30(3): 231-249.

Fan, J. P. H., L. H. P. Lang. 2000. The measurement of relatedness: An application to corporate diversification. J. Bus. 73(4): 629-660.

George, G. 2005. Slack resources and the performance of privately held firms. Acad. Manag. J. 48(4): 661-676.

Goldratt, E. M., J. Cox. 1986. The Goal: A Process of Ongoing Improvement. North River Press, New York.

Greve, H. R. 2003. A behavioral theory of R\&D expenditures and innovation: Evidence from shipbuilding. Acad. Manag. J. 46(6): 685-702.

Grossack, I. M. 1965. Towards an integration of static and dynamic measures of industry concentration. Rev. Econ. Stat. 47(3): 301-308.
Guide, V. D. R. J., R. Srivastava. 1998. Inventory buffers in recoverable manufacturing. J. Oper. Manag. 16(5): 551-568.

Hambrick, D., R. A. D'Aveni. 1988. Large corporate failures as downward spirals. Adm. Sci. Q. 33(1): 1-23.

Hanagal, D. D. 1992. Some inference results in bivariate exponential distributions rased on censored samples. Comm. Statist. Theory Methods 21(5): 1273-1295.

Hanagal, D. D. 2006. Bivariate Weibull regression model based on censored samples. Stat. Pap. 47(1): 137-147.

Haveman, H. 1992. Between a rock and a hard place: Organizational change and performance under conditions of fundamental environmental transformation. Adm. Sci. Q. 37(1): 48-75.

Headd, B. 2003. Redefining business success: Distinguishing between closure and failure. Small Bus. Econ. 21(1): 51-61.

Heckman, J. 1979. Sample selection bias as a specification error. Econometrica 47(1): 153-161.

Heeley, M., D. King, J. Covin. 2006. Effects of firm R\&D investment and environment on acquisition likelihood. J. Manag. Stud. 43(7): 1513-1535.

Hendricks, K. 1992. The output processes of serial production lines of exponential machines with finite buffers. Oper. Res. 40 (6): 1139-1147.

Hendricks, K., V. Singhal. 2005. An empirical analysis of the effect of supply chain disruptions on long-run stock price performance and equity risk of the firm. Prod. Oper. Manag. 14(1): 35-52.

Hendricks, K., V. Singhal. 2009. Demand-supply mismatches and stock market reaction: Evidence from excess inventory announcements. Manufact. Service Oper. Manage. 11(3): 509524.

Hendricks, K., V. Singhal, R. Zhang. 2009. The effect of operational slack, diversification, and vertical relatedness on the stock market reaction to supply chain disruptions. J. Oper. Manag. 27(3): 233-246.

Huang, Y.-F., C.-J. Chen. 2010. The impact of technological diversity and organizational slack on innovation. Technovation $\mathbf{3 0}$ (7-8): 420-428.

Inman, R. A., S. Mehra. 1993. Financial justification of JIT implementation. Inter. J. Oper. Prod. Manag. 13(4): 32-39.

Jovanovic, B.. 1982. Selection and the evolution of industry. Econometrica 50(3): 649-670.

Ju, M., H. Zhao. 2009. Behind organizational slack and firm performance in China: The moderating roles of ownership and competitive intensity. Asia Pac. J. Manag. 26(4): 701-717.

Karlsson, C., P. Ahlstrom. 1997. A lean and global smaller firm? Inter. J. Oper. Prod. Manage. 17(10): 940-952.

Keats, B., M. Hitt. 1988. A causal model of linkages among environmental dimensions, macro organizational characteristics, and performance. Acad. Manag. J. 31(3): 570-598.

Ketzenberg, M. E., G. C. Souza, V. D. R. J. Guide. 2003. Mixed assembly and disassembly operations for remanufacturing. Prod. Oper. Manag. 12(3): 320-335.

Kickul, J. R., M. D. Griffiths, J. Jayaram, S. M. Wagner. 2011. Operations management, entrepreneurship, and value creation: Emerging opportunities in a cross-disciplinary context. J. Oper. Manag. 29: 78-85.

Klein, J. P., M. L. Moeschberger. 2003. Survival Analysis: Techniques for Censored and Truncated Data. Springer Verlag, New York.

Kleindorfer, P. R., G. H. Saad. 2005. Managing disruption risks in supply chains. Prod. Oper. Manag. 14(1): 53-68.

Liao, J. J., J. R. Kickul, H. Ma. 2009. Organizational dynamic capability and innovation: An empirical examination of Internet firms. J. Small Bus. Manag. 47(3): 263-286.

Litschert, R., T. W. Bonham. 1978. A conceptual model of strategy formation. Acad. Manag. Rev. 3(2): 211-219. 
Love, E. G., N. Nohria. 2005. Reducing slack: The performance consequences of downsizing by large industrial firms, 197793. Strateg. Manag. J. 26(12): 1087-1108.

Metters, R., V. Vargas. 1999. A comparison of production scheduling policies on costs, service level, and schedule changes. Prod. Oper. Manag. 8(1): 76-91.

Milliken, F.. 1987. Three types of perceived uncertainty about the environment: State, effect, and response uncertainty. Acad. Manag. Rev. 12(1): 133-143.

Mishina, Y., T. G. Pollock, J. F. Porac. 2004. Are more resources always better for growth? Resource stickiness in market and product expansion. Strateg. Manag. J. 25(12): 1179-1197.

Mudholkar, G., D. Srivastava, G. Kollia. 1996. A generalization of the Weibull distribution with application to the analysis of survival. J. Am. Statist. Assoc. 91(436): 1575-1583.

Murphy, S. A.. 1995. Asymptotic theory for the frailty model. Ann. Stat. 23(1): 182-198.

Nohria, N., R. Gulati. 1996. Is slack good or bad for innovation? Acad. Manag. J. 39(5): 1245-1264.

Patel, P., A. Azadegan, L. Ellram. 2012. Supply chain orientation and operational performance: The moderating role of environmental dynamism. Decision Sci. J. Forthcoming.

Patzelt, H., D. A. Shepherd, D. Deeds, S. W. Bradley. 2008. Financial slack and venture managers' decisions to seek a new alliance. J. Bus. Ventur. 23(4): 465-481.

Phan, P., C. Chambers. 2012. Advancing theory in entrepreneurship from the lens of operations management. Prod. Oper. Manag. Forthcoming.

Piccolo, S., M. D'Amato, R. Martina. 2008. Product market competition and organizational slack under profit-target contracts. Int. J. Ind. Organ. 26(6): 1389-1406.

Rosenzweig, E. D. 2009. A contingent view of e-collaboration and performance in manufacturing. J. Oper. Manag. 27(6): 462-478.

Sharfman, M., G. Wolf, R. Chase, D. Tansik. 1988. Antecedents of organizational slack. Acad. Manag. Rev. 13(4): 601-614.

Shepherd, D., E. Douglas, M. Shanley. 2000. New venture survival: Ignorance, external shocks, and risk reduction strategies. J. Bus. Ventur. 15(5-6): 393-410.

Short, J. C., A. McKelvie, D. J. Ketchen, G. N. Chandler. 2009. Firm and industry effects on firm performance: A generalization and extension for new ventures. Strateg. Entrepreneurship J. 3(1): 47-65.

Simsek, Z., J. Veiga, M. Lubatkin. 2007. The impact of managerial environmental perceptions on corporate entrepreneurship: Towards understanding discretionary slack's pivotal role. J. Manag. Stud. 44(8): 1398-1424.

Singh, J. 1986. Performance, slack, and risk taking in organizational decision making. Acad. Manag. J. 29(3): 562-585.
Smith, K. G., J. R. Baum, E. A. Locke. 2001. A multidimensional model of venture growth. Acad. Manag. J. 44(2): 292-303.

Steele, D. C., K. E. Papke-Shields. 1993. Capacity slack: Strategic alternative to lead time. Prod. Inv. Manage. J. 34(4): $1-5$.

Stinchcombe, A. L. 1965. Social structure and organizations. J. G. March, ed., Handbook of Organizations. Rand McNally, Chicago, IL, 142-193.

Tan, J., M. W. Peng. 2003. Organizational slack and firm performance during economic transitions: Two studies from an emerging economy. Strateg. Manag. J. 24(13): 1249-1263.

Thompson, J. 1967. Organizations in Action. McGraw-Hill Companies, New York.

Van den Poel, D., B. Larivière. 2004. Attrition analysis for financial services using proportional hazard models. Eur. J. Oper. Res. 157(1): 196-217.

Vollman, T., W. Berry, D. Whybark. 1992. Manufacturing Planning and Control Systems. Irwin, Homewood, IL.

Voss, G. B., D. Sirdeshmukh, Z. G. Voss. 2008. The effects of slack resources and environmental threat on product exploration and exploitation. Acad. Manag. J. 51(1): 147-164.

Wan, W. P., D. W. Yiu. 2009. From crisis to opportunity: Environmental jolt, corporate acquisitions, and firm performance. Strateg. Manag. J. 30(7): 791-801.

Womack, J., D. Jones, D. Roos. 1990. The Machine that Changed the World. Macmillan, New York, NY.

\section{Supporting Information}

Additional Supporting Information may be found in the online version of this article:

Table S1: Step-Wise Model for Moderation Effects.

Table S2: Sub-Sample Robustness Tests: z-estimates of

Differences in Effects Between Sub-Samples.

Table S3: Quadratic Effects of Operational Slack.

Table S4: Alternate Distribution Specifications to Shared Frailty Weibull Distribution.

Table S5: Additional Controls Time-Varying Effects of Return on Sales, Return on Assets, and Return on Equity Lagged at $t-1$

Please note: Wiley-Blackwell is not responsible for the content or functionality of any supporting materials supplied by the authors. Any queries (other than missing material) should be directed to the corresponding author for the article. 